\title{
PENGARUH METODE PENGERINGAN DAN KONSENTRASI BUMBU SERTA LAMA PERENDAMAN DALAM LARUTAN BUMBU TERHADAP KUALITAS FISIK DAN SENSORI DENDENG BABI
}

\section{THE INFLUENCE OF DRYING METHODS, SEASONING CONCENTRATION AND CURING TIME ON PHYSICAL AND SENSORY QUALITY OF DRIED PORK}

\author{
Marcus Veerman ${ }^{1}$, Setiyono ${ }^{2}$, dan Rusman ${ }^{2}$ \\ ${ }^{1}$ Faculty of Agriculture, Pattimura University, Jl. Ir. M. Putuhena, Kampus Poka, Ambon, 97233 \\ ${ }^{2}$ Fakultas Peternakan, Universitas Gadjah Mada, J1. Fauna No. 3, Bulaksumur, Yogyakarta, 55281
}

\section{INTISARI}

Penelitian ini bertujuan untuk mengetahui pengaruh metode pengeringan dan konsentrasi bumbu serta lama perendaman terhadap $\mathrm{pH}$ dan sensori dendeng daging babi. Irisan daging direndam dalam larutan bumbu dengan konsentrasi 40, 20, 13,3, dan 10\%. Lamanya perendaman adalah 1, 3, 5, dan 7 jam, kemudian dilakukan pengeringan dengan sinar matahari dan oven. Parameter yang diamati meliputi $\mathrm{pH}$ dan parameter sensori. Data $\mathrm{pH}$ dianalisis dengan analisis variansi Rancangan Acak Lengkap pola faktorial $2 \times 4 \times 4$ dengan tiga kali ulangan, dan dilanjutkan dengan uji jarak berganda Duncan. Data uji sensori dianalisis dengan analisis non parametrik menggunakan uji Hedonik menurut Kruskal-Wallis, dilanjutkan analisis deskriptif kuantitatif (jaring labalaba) pada program MS Excel. Metode pengeringan dan konsentrasi bumbu serta lama perendaman, dan interaksi ketiga perlakuan berpengaruh sangat nyata $(\mathrm{P}<0,01)$ terhadap $\mathrm{pH}$ dendeng daging babi. Berdasarkan diagram jaring laba-laba, uji sensori meliputi parameter warna menunjukkan coklat sampai coklat keemasan, rasa menunjukkan agar suka sampai sangat suka dan daya terima menunjukkan agak suka sampai sangat suka. Metode pengeringan matahari menghasilkan tekstur kasar sampai agak kasar dan keempukan menunjukkan keras sampai agak keras. Metode pengeringan oven menunjukkan parameter warna agak coklat sampai coklat keemasan dan rasa agak suka sampai sangat suka, sedangkan daya terima tidak suka sampai agak suka, tekstur kasar sampai agak kasar dan keempukan keras sampai agak keras.

(Kata kunci: Dendeng babi, Kualitas pH, Uji sensori, Metode pengeringan, Konsentrasi bumbu)

\section{ABSTRACT}

The objective of this study was to determine the effect of drying methods, seasoning concentrations and curing times on the pH and sensory value of dried pork. Slices of meat were soaked in seasoning solutions at the concentration of 40,20, 13.3 and 10\% for 1, 3, 5 and 7 hours, and then were dried under the sun light and using oven (artificial drier). Each treatment has 3 replication. The observed parameters were physical quality ( $\mathrm{pH}$ value) and sensory value. The data of physical quality and sensory value were analyzed by analyses of variances with $2 \times 4 \times 4$ factorial arrangement with 3 replications, followed by Duncan's Multiple Range Test. Sensory value was analyzed as nonparametric analyses using Hedonic test by Kruskal-Wallis continued quantitative description analysis spider web by MS. Excel program. Drying methods, seasoning concentrations, curing time and interaction of the three treatments showed highly significant effects on $\mathrm{pH}(\mathrm{P}<0.01)$. Based on spider web, the meat dried under sunlight (solar drying) showed characteristic of color, flavor and consumer acceptability at the value of 3-5 and the value of texture and tenderness was 2-3. Meanwhile, the meat dried in the oven showed value of color and flavor 3-5 with the value of consumer acceptability, texture and tenderness 2-3.

(Key words: Drying methods, $\mathrm{pH}$, sensory value, Seasoning concentrations, Dried pork)

\section{Pendahuluan}

Daging merupakan salah satu bahan pangan yang bernilai gizi tinggi, karena selain mengandung protein yang berkualitas tinggi juga mengandung vitamin $\mathrm{B}$ komplek dan beberapa mineral. Kandungan air dan protein yang tinggi pada daging menyebabkan daging mudah mengalami kerusakan sehingga dapat

\footnotetext{
* Korespondensi (corresponding author):

Telp. +6285243530043

E-mail: marcus_veerman@yahoo.com
}

menurunkan daya gunanya. Mengatasi hal tersebut, maka dilakukan suatu usaha pengawetan untuk mencegah atau menghambat terjadinya kerusakan bahan makanan.

Daging merupakan bahan makanan asal ternak yang sangat diminati oleh sebagian besar penduduk di muka bumi ini, kecuali orang-orang tertentu yang memang tidak mengkonsumsi daging sebagai bahan makanan untuk memenuhi asupan gizinya. Daging mempunyai kandungan gizi yang sangat dibutuhkan oleh tubuh karena pada protein hewani memiliki komposisi 
asam amino yang lengkap dan seimbang (Riyanto, 2006; Soeparno, 2009).

Ternak babi merupakan salah satu jenis ternak penghasil daging dan berperan penting dalam pemenuhan kebutuhan protein hewani karena memiliki kandungan gizi yang tinggi. Komposisi kimia daging babi meliputi kadar air, lemak, dan protein berturut-turut adalah $60-70 \%, 6-10 \%$, dan 20-28\% (USDA, 2009).

Pengawetan daging merupakan suatu cara menyimpan daging untuk jangka waktu yang cukup lama agar kualitas maupun kebersihannya tetap terjaga. Tujuan pengawetan adalah menjaga ketahanan terhadap serangan jamur (kapang), bakteri, virus, dan kuman agar daging tidak mudah rusak. Ada beberapa cara pengawetan yaitu pendinginan, pelayuan, pengasapan, pengeringan, pengalengan, dan pembekuan (BPP Teknologi, 2000; Ray, 2007).

Deskripsi dendeng babi adalah produk makanan berbentuk lempengan yang terbuat dari irisan daging babi segar berasal dari babi sehat yang telah diberi bumbu dan dikeringkan sehingga kadar air tinggal 20\%. Pendapat lain menyatakan bahwa dendeng merupakan bahan pangan semi basah (intermediate moisture food) dengan kadar air 20 sampai 40\% (Fachruddin, 1997).

Dendeng adalah produk olahan tradisional dari daging yang merupakan hasil kombinasi proses curing dan pengeringan. Pembuatan dendeng merupakan salah satu alternatif pengolahan bahan pangan agar masa simpannya relatif lebih lama, dengan kadar air $20-40 \%$. Bumbu curing adalah garam dapur, sendawa (garam nitrat dan/atau nitrit), gula merupakan bahan utama, sedangkan merica, laos, ketumbar, dan bawang putih merupakan bumbu tambahan yang dapat meningkatkan palatabilitas dendeng (Suharyanto et al., 2008).

Pengawetan daging dengan jalan pengeringan dapat dilakukan dengan dua cara, yaitu dengan energi panas alam dan dengan menggunakan energi panas buatan melalui alat pengering. Pengeringan daging dalam pembuatan dendeng secara tradisional masih dilakukan dengan jalan menjemur daging tersebut di sinar matahari. Pembuatan dendeng dilakukan dengan cara pemeraman garam dari daging yang telah diiris tipis, kemudian dijemur, tanpa melakukan penambahan bumbu yang dapat memperbaiki cita rasa dan kualitas dendeng tersebut. Prinsip cara pengolahan dendeng adalah sama, yaitu irisan daging yang diberi bumbu, kemudian diperan pada suhu kamar selama 24 jam, dikeringkan dengan menggunakan panas matahari atau panas buatan sampai kadar air mencapai 20-25\% (Winarno, 1992).

Permasalahan yang dihadapi dalam pembuatan dendeng adalah belum diketahuinya pengaruh perlakuan metode pengeringan, konsentrasi bumbu, dan lama perendaman terhadap kualitas fisik dan sensori. Sehingga perlu dilakukan penelitian tentang metode pengeringan dan konsentrasi bumbu serta lama perendaman daging dalam bumbu guna mengetahui kualitas yang dihasilkan.

Penelitian ini bertujuan untuk mengetahui pengaruh metode pengeringan yang digunakan dan konsentrasi bumbu serta lama perendaman terhadap kualitas dendeng babi yang meliputi kualitas fisik dan sensori dendeng.

\section{Materi dan Metode}

Bahan yang digunakan untuk pembuatan dendeng adalah daging babi bagian longissimus sebanyak $80 \mathrm{~kg}$, akuades, tissue, dan bumbu yang terdiri dari gula kelapa, garam dapur, bawang putih, jahe, laos, dan ketumbar. Alat yang digunakan dalam penelitian meliputi $\mathrm{pH}$ meter, pompa vakum, foodscan, erlenmeyer, oven (merek Memmert), tabung reaksi, pisau, talenan, blender, plastik vakum, glas beker, dan termometer.

\section{Metode}

Pembuatan dendeng. Pembuatan dendeng meliputi pembersihan daging dari urat dan diiris tipis setebal $\pm 5 \mathrm{~mm}$. Bumbu dihaluskan dengan menggunakan blender (merek Phillips). Daging yang telah bersih dan diiris tipis ditimbang $1 \mathrm{~kg}$ untuk tiap perlakuan. Irisan daging kemudian direndam dalam larutan bumbu dengan konsentrasi $40,20,13,3$, dan $10 \%$. Lamanya perendaman adalah $1,3,5$, dan 7 jam. Adonan bumbu yang dipakai untuk perendamaan $1 \mathrm{~kg}$ daging adalah garam $30 \mathrm{~g}$, gula kelapa $5 \mathrm{~g}$, bawang putih $15 \mathrm{~g}$, jahe $25 \mathrm{~g}$, laos $10 \mathrm{~g}$, dan ketumbar $15 \mathrm{~g}$.

Daging yang telah direndam diangkat dan dibiarkan airnya menetes kemudian dijemur pada sinar matahari untuk sampel pengeringan menggunakan matahari sedangkan pengeringan dengan menggunakan oven, daging dimasukkan ke dalam oven dengan suhu $60^{\circ} \mathrm{C}$ selama 48 jam, daging yang telah kering (dendeng) dimasukkan ke dalam kantong plastik dan selanjutnya dimasukkan ke dalam kotak dan disimpan pada suhu kamar 26-30 ${ }^{\circ} \mathrm{C}$ untuk selanjutnya dianalisis.

Pengujian pH dendeng babi. Pengukuran $\mathrm{pH}$ menggunakan metode seperti yang dikemukakan oleh AOAC (2005), sebagai berikut: sampel seberat $10 \mathrm{~g}$ dicincang halus kemudian dicampur dengan $20 \mathrm{ml}$ akuades dan dihomogenkan selama 30 detik, dan diukur $\mathrm{pH}$ larutannya. Semua pengukuran diulang sebanyak tiga kali.

Pengujian sensori dendeng babi. Pengujian ini menggunakan metode skoring dengan 15 orang panelis. Panelis yang digunakan merupakan panelis yang tidak terlatih dengan mengisi angket yang disediakan. 
Nilai ranking skor pada pengujian meliputi warna, rasa, tekstur, keempukan, dan daya terima (Tabel 1).

\section{Analisis statistik}

Rancangan percobaan yang digunakan dalam penelitian ini adalah Rancangan Acak Lengkap pola faktorial $(2 \times 4 \times 4)$ dengan tiga kali ulangan. Pengujian beda rataan antar tiap perlakuan menggunakan uji jarak berganda Duncan. Pengujian sensori menggunakan analisis non parametrik menggunakan uji Hedonik menurut Kruskal-Wallis dan dilanjutkan dengan analisis deskriptif kuantitatif (jaring laba-laba) menggunakan program MS Office Excel.

\section{Hasil dan Pembahasan}

\section{pH dendeng babi}

Hasil analisis statistik menunjukkan bahwa metode pengeringan, konsentrasi bumbu, dan lama perendaman berpengaruh sangat nyata $(\mathrm{P}<0,01)$ terhadap $\mathrm{pH}$ dendeng babi. Hasil analisis statistik menunjukkan bahwa interaksi perlakuan metode pengeringan vs. konsentrasi bumbu, konsentrasi bumbu vs. lama perendaman, tidak berpengaruh nyata terhadap $\mathrm{pH}$ dendeng babi. Sedangkan interaksi perlakuan metode pengeringan vs. lama perendaman dan metode pengeringan vs. konsentrasi bumbu vs. lama perendaman berpengaruh sangat nyata $(\mathrm{P}<0,01)$ terhadap $\mathrm{pH}$ dendeng babi. Hal ini menunjukkan bahwa $\mathrm{pH}$ dendeng babi lebih dipengaruhi oleh perlakuan faktor tunggal dibandingkan faktor interaksinya, kecuali untuk interaksi perlakuan metode pengeringan vs. lama perendaman dan metode pengeringan vs. konsentrasi bumbu vs. lama perendaman. Perlakuan metode pengeringan menyebabkan perubahan $\mathrm{pH}$ karena perubahan kadar air bahan. Perlakuan konsentrasi bumbu dan lama perendaman berpengaruh karena terjadi penetrasi air dan juga bumbu yang menyebabkan perubahan $\mathrm{pH}$. Rataan $\mathrm{pH}$ dendeng babi berkisar antara 5,29-6,64 (Tabel 2). Hasil penelitian ini relatif sama dengan hasil penelitian
Suharyanto et al. (2008), yang menyatakan bahwa rataan $\mathrm{pH}$ dendeng daging kuda, domba, dan sapi berturut-turut adalah 5,16, 5,94, dan 5,83.

Metode pengeringan dengan menggunakan sinar matahari cenderung menghasilkan rerata $\mathrm{pH}$ dendeng babi yang lebih rendah $(5,83)$ dibandingkan dengan metode pengeringan oven $(6,16)$. Perbedaan $\mathrm{pH}$ dendeng disebabkan karena pengaruh panas selama proses pengeringan sehingga terjadi perubahan pada protein otot. Forrest et al. (1975) menyatakan terjadinya peningkatan $\mathrm{pH}$ yang nyata bila protein otot dipengaruhi oleh panas dan karena pecahnya kelompok asam amino reaktif histidin.

$\mathrm{pH}$ dendeng babi tertinggi 6,64 ditunjukkan pada perlakuan dengan metode pengeringan matahari vs. konsentrasi bumbu $13,3 \%$ vs. lama perendaman 5 jam, dapat dinyatakan dalam kisaran normal. Bila $\mathrm{pH}$ daging meningkat, misalnya dari 5,2 sampai $\mathrm{pH}$ 6,8, atau lebih dari titik isoelektrik protein-protein miofibrilar, daya ikat air protein daging akan meningkat (Soeparno, 2011).

Pengaruh perlakuan konsentrasi bumbu terhadap $\mathrm{pH}$ dendeng babi cenderung meningkat dari konsentrasi $40 \%$ (pH 5,76) ke 13,3\% (pH 6,18), kemudian menurun pada konsentrasi bumbu 10\% (pH 6,02). Peningkatan $\mathrm{pH}$ pada dendeng ini lebih disebabkan karena proses pengolahan dimana semakin tinggi konsentrasi bumbu maka dendeng semakin asam. Rataan $\mathrm{pH}$ dendeng babi cenderung menurun seiring meningkatnya lama perendaman daging babi dalam bumbu yaitu dari 6,08 (1 jam) menjadi 5,99 (3 jam) dan meningkat pada lama perendaman 5 jam $(6,09)$ kemudian menurun pada lama perendaman 7 jam $(5,83)$. Peningkatan $\mathrm{pH}$ pada dendeng lebih disebabkan karena proses pengolahan dimana semakin lama merendam maka menurunkan $\mathrm{pH}$ dendeng. Forrest et al. (1975) menyatakan bahwa perlakuan selama proses pengolahan daging dapat mengubah nilai $\mathrm{pH}$. Daya ikat air daging merupakan faktor yang penting dalam menentukan mutu dan dapat pula menaikkan dan menurunkan $\mathrm{pH}$ (Soeparno, 2009).

Tabel 1. Skor pengujian sensori (score of sensory analysis)

\begin{tabular}{|c|c|c|c|c|c|}
\hline $\begin{array}{c}\text { Skor } \\
\text { (score) }\end{array}$ & Warna (color) & Rasa (taste) & Tekstur (texture) & $\begin{array}{l}\text { Keempukan } \\
\text { (tenderness) }\end{array}$ & $\begin{array}{c}\text { Daya terima } \\
\text { (acceptability) }\end{array}$ \\
\hline 1 & Abu-abu (grey) & $\begin{array}{l}\text { Sangat tidak suka } \\
\text { (very unlike) }\end{array}$ & $\begin{array}{l}\text { Sangat kasar } \\
\text { (very rough) }\end{array}$ & $\begin{array}{l}\text { Sangat keras } \\
\text { (very tough) }\end{array}$ & $\begin{array}{l}\text { Sangat tidak suka } \\
\text { (very unacceptable) }\end{array}$ \\
\hline 2 & $\begin{array}{l}\text { Coklat keputihan } \\
\text { (white brown) }\end{array}$ & $\begin{array}{l}\text { Tidak suka } \\
\text { (unlike) }\end{array}$ & Kasar (rough) & Keras (tough) & $\begin{array}{l}\text { Tidak suka } \\
\text { (unacceptable) }\end{array}$ \\
\hline 3 & $\begin{array}{l}\text { Agak coklat } \\
\text { (light brown) }\end{array}$ & $\begin{array}{l}\text { Agak suka } \\
\text { (rather like) }\end{array}$ & $\begin{array}{l}\text { Agak kasar } \\
\text { (rather rough) }\end{array}$ & $\begin{array}{l}\text { Agak keras } \\
\text { (rather tough) }\end{array}$ & $\begin{array}{l}\text { Agak suka (rather } \\
\text { acceptable) }\end{array}$ \\
\hline 4 & Coklat (brown) & Suka (like) & Halus (smooth) & $\begin{array}{l}\text { Agak empuk } \\
\text { (rather tender) }\end{array}$ & Suka (acceptable) \\
\hline 5 & $\begin{array}{l}\text { Coklat keemasan } \\
\text { (gold brown) }\end{array}$ & $\begin{array}{l}\text { Sangat suka } \\
\text { (very like) }\end{array}$ & $\begin{array}{l}\text { Sangat halus } \\
\text { (very smooth) }\end{array}$ & Empuk (tender) & $\begin{array}{l}\text { Sangat suka (very } \\
\text { acceptable) }\end{array}$ \\
\hline
\end{tabular}


Tabel 2. Rataan dan standar deviasi pH dendeng babi sebagai pengaruh interaksi perlakuan metode pengeringan vs. konsentrasi bumbu vs. lama perendaman (average and standard deviation for $\mathrm{pH}$ of dried pork as drying method, seasoning concentration and curing time interaction treatment)

\begin{tabular}{|c|c|c|c|c|c|c|c|}
\hline \multirow{2}{*}{\multicolumn{2}{|c|}{$\begin{array}{l}\text { Lama } \\
\text { perendaman } \\
\text { (jam) (curing } \\
\text { time (hour)) } \\
\end{array}$}} & \multirow{2}{*}{$\begin{array}{l}\text { Metode pengeringan } \\
\text { (drying method) }\end{array}$} & \multicolumn{4}{|c|}{ Konsentrasi bumbu (\%) (seasoning concentration (\%)) } & \multirow{2}{*}{$\begin{array}{c}\text { Rerata lama } \\
\text { perendaman } \\
\text { (average curing } \\
\text { time) }\end{array}$} \\
\hline & & & 40 & 20 & 13,3 & 10 & \\
\hline \multirow{2}{*}{\multicolumn{2}{|c|}{1}} & & & & & & $576+023^{c}$ \\
\hline & & Oven & $6,02 \pm 0,40^{\mathrm{aA}}$ & $6,10 \pm 0,34^{\mathrm{aAB}}$ & $6,24 \pm 0,38^{\mathrm{aAB}}$ & $6,09 \pm 0,44^{\mathrm{aA}}$ & $J, 10+0,2 J$ \\
\hline \multirow{2}{*}{\multicolumn{2}{|c|}{3}} & tahari (sun light) & $5,33 \pm 0,04^{\mathrm{cC}}$ & $6,34 \pm 0,37^{\mathrm{abA}}$ & $6,52 \pm 0,60^{\mathrm{aA}}$ & $5,86 \pm 0,26^{\mathrm{bB}}$ & $6,03 \pm 0,19^{\mathrm{b}}$ \\
\hline & & Oven & $5,88 \pm 0,02^{\mathrm{bA}}$ & $5,91 \pm 0,08^{\mathrm{bB}}$ & $5,89 \pm 0,19^{\mathrm{bB}}$ & $6,22 \pm 0,17^{\mathrm{abA}}$ & \\
\hline \multirow{2}{*}{\multicolumn{2}{|c|}{5}} & Sinar matahari (sun light) & $5,65 \pm 0,01^{\mathrm{eB}}$ & $5,84 \pm 0,05^{\mathrm{deA}}$ & $5,96 \pm 0,05^{\mathrm{cd} A \mathrm{~B}}$ & $5,83 \pm 0,08^{\mathrm{deB}}$ & $6,18 \pm 0,12^{\mathrm{a}}$ \\
\hline & & Oven & $6,04 \pm 0,14^{\mathrm{cA}}$ & $6,31 \pm 0,09^{\mathrm{bA}}$ & $6,64 \pm 0,18^{\mathrm{aA}}$ & $6,46 \pm 0,13^{\mathrm{bA}}$ & \\
\hline \multirow{2}{*}{\multicolumn{2}{|c|}{7}} & & $531+0 \Omega 4^{\mathrm{eC}}$ & $520+0 \Omega 2^{\mathrm{eC}}$ & $571+026 \mathrm{cdB}$ & $544+016$ & $603+022^{\mathrm{b}}$ \\
\hline & & Oven & $5,92 \pm 0,29^{\mathrm{bcA}}$ & $6,31 \pm 0,13^{\text {aA }}$ & $6,52 \pm 0,07^{\mathrm{aA}}$ & $\begin{array}{l}5,44 \pm 0,10 \\
6,16 \pm 0,35^{\mathrm{abA}}\end{array}$ & $0,03 \pm 0, \angle 2$ \\
\hline \multirow{2}{*}{\multicolumn{3}{|c|}{$\begin{array}{l}\text { Rerata konsentrasi bumbu (average } \\
\text { seasoning concentration) } \\
\text { Rerata metode pengeringan (average } \\
\text { drying method) }\end{array}$}} & $6,08 \pm 0,18^{\mathrm{a}}$ & $5,99 \pm 0,12^{\mathrm{a}}$ & $6,09 \pm 0,28^{\mathrm{a}}$ & $5,83 \pm 0,21^{b}$ & \\
\hline & & & & & & & \\
\hline \multicolumn{3}{|c|}{ Sinar matahari (sun light) } & $5,83 \pm 0,28^{\mathrm{b}}$ & & & & \\
\hline \multicolumn{3}{|c|}{ Oven } & $6,17 \pm 0,11^{\mathrm{a}}$ & & & & \\
\hline \multicolumn{3}{|c|}{$\overline{a, b, c, c, d, e}$ Super } & m yang sam & $\begin{array}{l}\text { menunjukka } \\
\text { ces }(P<0.05)\end{array}$ & erbedaan $(\mathrm{P}<$ & $0,05)($ differe & it superscripts \\
\hline \multicolumn{3}{|l|}{$\mathrm{A}, \mathrm{B}, \mathrm{C}$} & s yang sama & nenunjukkan & & & \\
\hline
\end{tabular}

\section{Sensori dendeng babi}

Hasil pengujian kualitas sensori dendeng babi merupakan parameter dalam menilai baik atau tidaknya dendeng babi dilihat dari segi sensori. Kualitas sensori dendeng babi dalam penelitian ini meliputi uji warna, rasa, tekstur, keempukan, dan daya terima.

Hasil uji sensori dendeng babi disajikan dalam bentuk diagram jaring laba-laba (Gambar 1 dan 2) untuk mengetahui hubungan antara parameter. Berdasarkan diagram jaring laba-laba, parameter warna, rasa, dan daya terima menunjukkan skor 3 sampai 5 , sedangkan tekstur dan keempukan menunjukkan skor 2 sampai 3, untuk metode pengeringan matahari, sedangkan metode pengeringan oven, parameter warna dan rasa menunjukkan skor 3 sampai 5, sedangkan daya terima, tekstur dan keempukan menunjukkan skor 2 sampai 3. Keseluruhan parameter menunjukkan skor lebih dari 2.

Analisis rataan tiap parameter menunjukkan bahwa metode pengeringan matahari menunjukkan skor nilai rataan yang lebih tinggi dibandingkan metode pengeringan oven terhadap parameter warna, rasa, dan daya terima; tekstur antara kedua metode relatif sama; tetapi skor parameter keempukan lebih tinggi ditunjukkan oleh metode pengeringan oven.
Warna. Warna merupakan salah satu unsur kualitas organoleptik yang penting bagi produk daging, karena apabila tidak ada kesesuaian dengan bahan makanan, maka produk tersebut tidak disukai atau diminati oleh konsumen (Naruki dan Kanoni, 1992).

Hasil pengujian Kruskal-Wallis untuk warna daging dendeng babi tidak berbeda nyata antara perlakuan metode pengeringan matahari dan oven. Ratarata nilai warna dendeng babi dari coklat sampai ke coklat keemasan. Warna akhir dari daging olahan tergantung pada perubahan pigmen yang terjadi selama pemanasan, selama pemanasan warna daging akan berubah secara berangsur-angsur dari merah cerah menjadi abu-abu atau cokelat. Hal ini terjadi karena adanya reaksi antara gula pereduksi dengan asam amino secara non enzimatis hingga terbentuk pigmen melanoidin (Bailey, 1998).

Hasil pengujian Kruskal-Wallis untuk warna daging dendeng babi tidak berbeda nyata antara perlakuan konsentrasi bumbu. Hal ini disebabkan karena pengaruh konsentrasi bumbu belum efektif untuk melarutkan mioglobin yang merupakan protein sarkoplasmik sebagai protein utama penentu warna daging sehingga warna dendeng babi masih relatif sama. Lawrie (1995) menyatakan bahwa mioglobin sebagai salah satu 
dari protein sarkoplasmik mempunyai peranan besar dalam menentukan warna daging.

Hasil pengujian Kruskal-Wallis untuk warna daging dendeng babi berbeda nyata $(\mathrm{P}<0,05)$ antara perlakuan lama perendaman. Hal ini disebabkan karena daging yang direndam dalam larutan dengan lama perendaman yang berbeda sehingga penyerapan yang terjadi juga berbeda maka pada warna juga terjadi perbedaan. Perubahan warna daging yang diolah dipengaruhi oleh lama dan suhu pengolahan (Lawrie, 1995). Perubahan terjadi selama pemanasan sehubungan dengan bahan-bahan yang ditambahkan (Naruki, 1991).

Rasa. Hasil pengujian Kruskal-Wallis untuk rasa daging dendeng babi berbeda nyata $(\mathrm{P}<0,05)$ antara perlakuan metode pengeringan matahari dan oven. Ratarata skor rasa yang dihasilkan dari agak suka sampai dengan sangat suka. Rasa dendeng ini berhubungan dengan lemak dalam daging dan bumbu-bumbu yang digunakan. Rasa merupakan komponen yang menentukan kualitas produk daging olahan, walaupun dari segi gizi yang dikandung hanya sedikit pengaruhnya tetapi sangat menentukan selera konsumen. Formulasi bahan penyedap dan bumbu yang berbeda menghasilkan produk daging proses dengan citra rasa yang berbeda (Soeparno, 2009).

Selama pembumbuan dan pengeringan akan terjadi pembentukan cita rasa yang akan menambah rasa dan aroma dendeng menjadi lebih sedap. Asam amino bebas merupakan salah satu komponen yang berpengaruh langsung terhadap rasa produk daging curing kering (Toldra dan Floes, 1998) selanjutnya dinyatakan bahwa asam amino bebas dihasilkan oleh aktivitas enzim protease otot (katepsin, kalpain, peptidase, dan aminopeptidase) dan enzim lipase otot (lipase asam lisosomal, asam fosfolipase, dan lipase jaringan adipose). Aktivitas enzim-enzim ini sangat dipengaruhi oleh proses

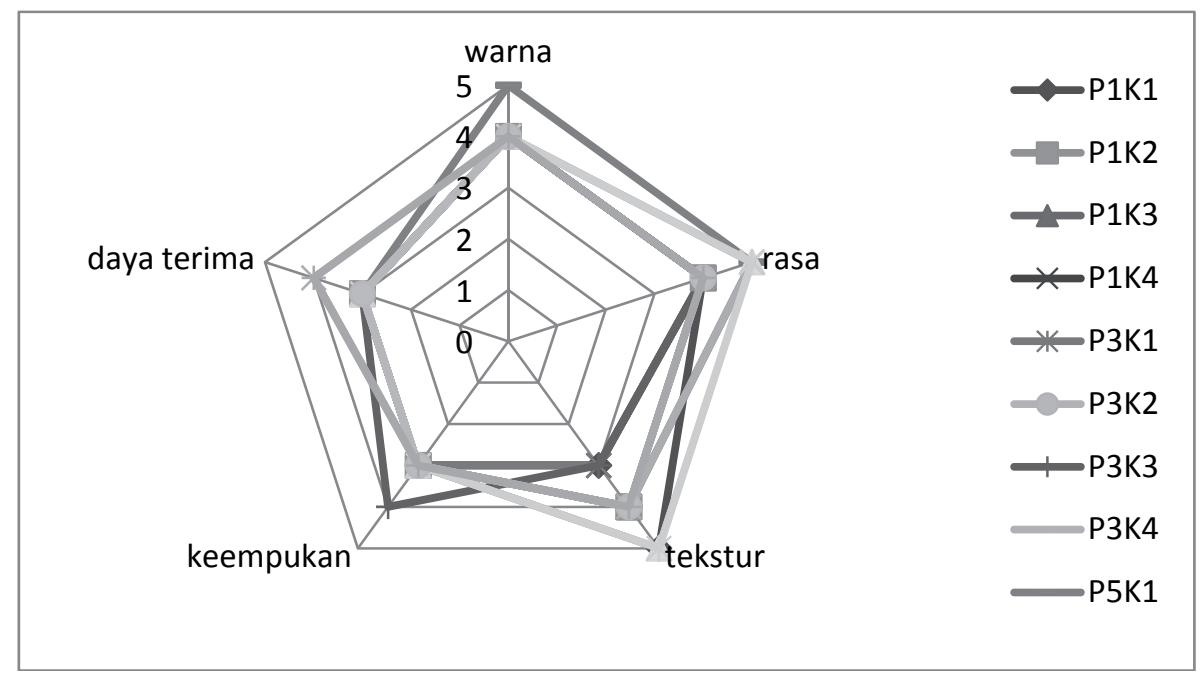

Gambar 1. Spider web hasil uji sensori dendeng babi yang dikeringkan dengan metode pengeringan matahari. $\mathrm{P}=$ lama perendaman (jam). $\mathrm{K}=$ konsentrasi bumbu (\%). (Spider web of sensory analysis for dried pork with sun-drying method. $P=$ length of curing (hour). $K=$ concentration of seasoning $(\%)$ ).

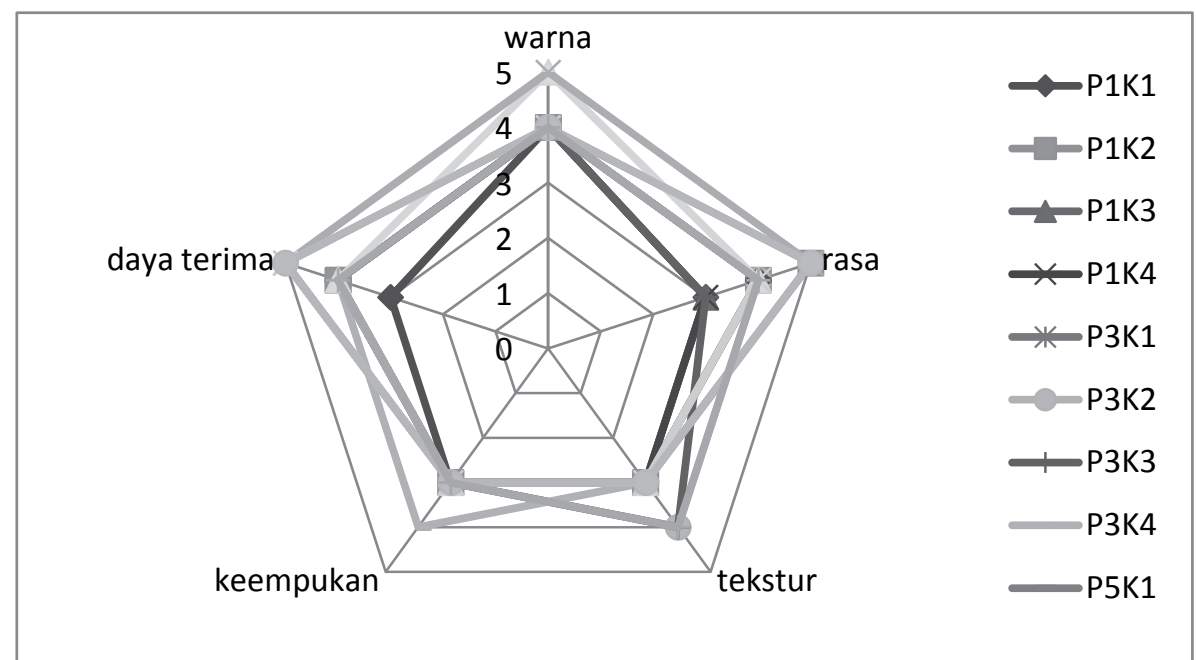

Gambar 2. Spider web hasil uji sensori dendeng babi yang dikeringkan dengan metode pengeringan oven. $\mathrm{P}=$ lama perendaman (jam). $\mathrm{K}=$ konsentrasi bumbu (\%). (Spider web of sensory analysis for dried pork with ovendrying method. $P=$ length of curing (hour). $K=$ concentration of seasoning $(\%)$ ). 
pengeringan selama prosesing daging curing kering. Pengeringan menyebabkan nilai $a_{w}$ menurun yaitu sekitar 0,90 di bagian dalam dan 0,85 di bagian permukaan daging, $a_{w}$ penting untuk mengontrol aktivitas enzim.

Tekstur. Tekstur merupakan atribut bahan pangan sebagai penentu dipilihnya suatu bahan pangan tertentu, tetapi bila dibandingkan dengan sifat mikroorganisme dan potensi gizi, tekstur kurang mendapat perhatian yang serius (Hardiman, 1991). Menurut van Laack et al. (2001) keempukan daging merupakan suatu karakteristik kualitas yang kompleks yang dipengaruhi oleh banyak faktor, termasuk faktor biokimiawi sebelum dan setelah penyembelihan.

Hasil pengujian Kruskal-Wallis untuk tekstur daging dendeng babi tidak berbeda nyata antara perlakuan metode pengeringan matahari dan oven. Ratarata nilai tekstur dendeng babi adalah dari kasar sampai dengan agak kasar. Tekstur ini disebabkan karena pada pembuatan dendeng babi ada penambahan bumbubumbu sehingga dapat mempengaruhi tekstur. Tekstur daging olahan sangat dipengaruhi oleh macam daging yang digunakan, metode pengolahan dan bahan-bahan yang ditambahkan. Forrest et al. (1975) mengatakan bahwa, pengolahan yang baik dan pemberian bahanbahan tambahan seperti garam, gula, dan lain-lain mempengaruhi tekstur. Tekstur dendeng dipengaruhi oleh penampilan dan kesan yang diberikan oleh panca indera.

Keempukan. Hasil pengujian Kruskal-Wallis untuk keempukan daging dendeng babi tidak berbeda nyata antara perlakuan metode pengeringan matahari dan oven. Rata-rata nilai keempukan dendeng menunjukkan keras sampai agak keras. Nilai keempukan yang lebih empuk ditunjukkan oleh dendeng yang dikeringkan menggunakan metode matahari. Dendeng babi sedikit lebih empuk karena terdapat lapisan lemak pada bagian serat-serat daging tersebut. Pemanasan yang dilakukan selama proses pembuatan dendeng ini tidak dapat merubah struktur ikatan kolagen pada daging, yang merupakan faktor penentu utama keempukan daging, sehingga perbedaan keempukan yang diperoleh dari dua perlakuan.

Keempukan daging adalah kualitas daging setelah dimasak berdasarkan kemudahan untuk dikunyah tanpa kehilangan sifat dan jaringan yang layak. Keempukan dan tekstur daging kemungkinan besar merupakan penentu yang penting pada kualitas daging (Lawrie, 1995).

Daya terima. Hasil pengujian Kruskal-Wallis untuk daya terima daging dendeng babi berbeda nyata $(\mathrm{P}<0,05)$ antara perlakuan metode pengeringan matahari dan oven. Rata-rata daya terima dari agak suka sampai dengan suka, mengindikasikan bahwa dendeng babi dapat diterima oleh panelis. Hal ini disebabkan karena perlakuan metode pengeringan, konsentrasi bumbu, dan lama perendaman memberikan pengaruh terhadap kualitas sensori dendeng secara keseluruhan. Berdasarkan hasil penelitian ini menunjukkan bahwa dendeng babi yang lebih disukai panelis adalah hasil pengeringan dengan metode pengeringan matahari yang menghasilkan daging lebih empuk.

Winarno (1992) menyatakan bahwa rasa suka atau penerimaan secara keseluruhan terhadap bahan pangan yang ada dalam mulut adalah interaksi kimia dengan reseptor melalui suatu proses yang rumit dan komplek sehinga melalui proses ini kesukaan suatu bahan pangan yang dikonsumsi dapat diketahui lewat persepsinya. Adat istiadat atau kebiasaan konsumen sangat mempengaruhi daya terima (Lawrie, 1995).

\section{Kesimpulan}

Berdasarkan $\mathrm{pH}$, dendeng babi dengan kualitas terbaik diperoleh dengan metode pengeringan matahari, konsentrasi bumbu $13,3 \%$ dan lama perendaman 5 jam. Berdasarkan parameter warna, rasa, dan daya terima, dendeng babi yang dikeringkan dengan metode pengeringan matahari menunjukkan skor nilai rataan yang lebih tinggi. Berdasarkan tekstur, dendeng babi yang dikeringkan menggunakan kedua metode menunjukkan hasil yang relatif sama. Skor parameter keempukan tertinggi ditunjukkan oleh metode pengeringan matahari.

\section{Daftar Pustaka}

AOAC. 2005. Official Methods of Analysis. Association of Official Analytical Chemists, $18^{\text {th }} \mathrm{ed}$, Washington, DC.

Bailey, M. E. 1998. Maillard reactions and meat flavour development. In: Flavour of Meat Product and Seafood. $2^{\text {nd }}$ ed. F. Shahidi (ed.). Blackie Academic and Profesional, New York.

BPP Teknologi. 2000. Dendeng Sayat. BPP Teknologi, Jakarta.

Fachruddin, L. 1997. Membuat Aneka Dendeng. Kanisius, Yogyakarta.

Forrest, J. C., E. D. Aberle, H. B. Hedrick, M. D. Judge and R. A. Merkel. 1975. Principles of Meat Science. W. H. Freeman and Co., San Fransisco.

Hardiman. 1991. Tekstur Pangan. Pada Kursus Singkat Sensori Pangan. Pusat Antar Universitas Pangan dan Gizi. Universitas Gadjah Mada. Yogyakarta.

Lawrie, R. A. 1995. Ilmu Daging. Edisi Kelima. Penterjemah Aminuddin Parakkasi dan Yuda Amwila. Penerbit Universitas Indonesia (UIPress). Jakarta. 
Naruki, S. 1991. Kimia dan Teknologi Pengolahan Daging. PAU Pangan Gizi UGM, Yogyakarta.

Naruki, S. dan S. Kanoni. 1992. Kimia dan Teknologi Hasil Pengolahan Hewan I. Pusat Antar Universitas, Pangan dan Gizi, Universitas Gadjah Mada, Yogyakarta.

Ray, F. K. 2007. Meat Curing. Oklahoma Cooperative Extenzion Service ANSI-3994. Division of Agricultural Sciences and Natural Resources, Oklahoma State University. Oklahoma.

Riyanto, I. 2006. Analisis kadar, daya cerna dan karakteristik protein daging ayam kampung dan olahannya. Skripsi. Program Studi Teknologi Hasil Ternak. Fakultas Peternakan Institut Pertanian Bogor.

Soeparno. 2009. Ilmu dan Teknologi Daging. Cetakan ke-5. Gadjah Mada University Press, Yogyakarta.

Soeparno. 2011. Ilmu Nutrisi dan Gizi Daging. Cetakan ke-1. Gadjah Mada University Press, Yogyakarta.
Suharyanto, R. Priyanto, dan E. Gunardi. 2008. Sifat fisiko-kimia dendeng daging giling terkait cara pencucian (leaching) dan jenis daging yang berbeda. Media Peternakan 31: 99-106.

Toldra, F. and M. Floes. 1998. The role of muscle proteases and lipases in flavor developmen during the processing of dry-cured ham. Food Sci. Nutr. 38: 331-352.

USDA. 2009. USDA Nutrient Data Set for Fresh Pork (From SR), Release 2.0. U.S. Department of Agriculture. Agricultural Research Service. Maryland, USA.

van Laack, R. L., S. G. Stevens and K. J. Stalders. 2001. The influence of ultimate $\mathrm{pH}$ and intramuscular fat content on pork tenderness and tenderization. J. Anim. Sci. 79: 392-397.

Winarno. 1992. Kimia Pangan dan Gizi. PT Gramedia, Jakarta. 